\title{
Effects of Allium victorialis leaf extracts and its single compounds on aldose reductase, advanced glycation end products and TGF- $\beta 1$ expression in mesangial cells
}

Young Sook Kim', Dong Ho Jung ${ }^{1}$, Ik Soo Lee', So-Jin Choi', Song Yi Yu', Sea-Kwang Ku², Myung-Hwa Kim³,4 and Jin Sook Kim ${ }^{1 *}$

\begin{abstract}
Background: Accumulating evidences suggest that aldose reductase (AR) inhibitors and advanced glycation end product (AGE) formation inhibitors may prevent chronic hyperglycemia-induced long-term complication in diabetes. Transforming growth factor-beta1 (TGF- $\beta 1$ ) plays an important role in the development of diabetic nephropathy. Allium species have been utilized in folk medicine throughout the world for the treatment of various physical disorders. However, the benefits of Allium victorialis (A. victorialis) against diabetic complications, especially nephropathy, have yet to be explored. In the present study, we investigated the protective effect of the compounds isolated from $A$. victorialis leaf on diabetic nephropathy.

Methods: In vitro AR activity, AGEs formation, and AGE-receptor for AGEs (RAGE) binding in human RAGE (hRAGE)-overexpressing cells were tested. High glucose-induced transforming growth factor-beta1 (TGF- $\beta 1$ ) expression was also examined in mouse kidney mesangial cells (MMCs) cultured under high glucose.

Results: Of the isolated eight compounds from A. victorialis leaf extracts tested, quercitrin exhibited the most pronounced inhibitory effects on AR activity $\left(I C_{50}\right.$ value of $\left.0.17 \mu \mathrm{M}\right)$ and $A G E s$ formation $\left(I C_{50}\right.$ value of $\left.4.20 \mu \mathrm{M}\right)$. Furthermore, quercitrin disrupted AGE-RAGE binding in a concentration-dependent manner in hRAGE-overexpressing cells. Additionally, of the eight compounds tested, ferulic acid significantly reduced high glucose-induced TGF- $\beta 1$ expression and secretion in MMCs.
\end{abstract}

Conclusions: Our results suggest that active compounds isolated from A. victorialis leaf exhibit inhibitory effects on AR activity in rat lenses and AGE formation. Further, ferulic acid reduces TGF- $\beta 1$ mRNA expression and secretion in MMCs under diabetic conditions. Thus, A. victorialis is a good candidate for the development of treatments for diabetic nephropathy.

Keywords: Allium victorialis, Aldose reductase, Advanced glycation end products, Diabetic nephropathy, transforming growth factor-beta1, Mouse mesangial cells

\footnotetext{
* Correspondence: jskim@kiom.re.kr

'Korean Medicine-Based Herbal Drug Development Group, Herbal Medicine Research Division, Korea Institute of Oriental Medicine (KIOM), Daejeon, Republic of Korea

Full list of author information is available at the end of the article
} 


\section{Background}

Chronic hyperglycemia is the most common feature of all forms of diabetes mellitus, and it accelerates the induction of aldose reductase (AR, EC 1.1.1.21) and the irreversible formation of advanced glycation end products (AGEs), which play important roles in the pathogenesis of diabetic complications [1]. Diabetic nephropathy is a major complication of diabetes mellitus, and although the mechanism of glomerulosclerosis still remains unclear, the irreversible formation of AGEs, polyol accumulation, and oxidative stress have been considered the major causes of diabetic nephropathy [2]. AR, the first rate-limiting enzyme in the polyol pathway, is present in the eyes, kidneys, and other tissues affected by diabetic complications. Increased glucose enters the polyol pathway, where it is reduced by AR to sorbitol [2,3]. AR inhibitors (ARIs), such as epalrestat, 3,3tetramethyleneglutaric acid (TMG), and fidarestat, have been developed, and some have been revealed to prevent diabetic nephropathy in animal models or patients [3-7]. ARIs from natural products have been found to prevent or delay the development of diabetic complications in animal models [8-10].

Transforming growth factor-beta 1 (TGF- $\beta 1$ ) is a multifunctional cytokine that plays important roles in cell proliferation, wound healing, differentiation, apoptosis, and the immune response in several cells [11]. In particular, TGF- $\beta 1$ is a key mediator of diabetic nephropathy that increases the levels of extracellular matrix (ECM) proteins, such as collagen I and IV, laminin, and fibronectin, in the glomeruli [11]. In addition, TGF- $\beta$ has been identified as a critical regulator and mediator of pathophysiological processes of ocular tissue development or repair. TGF- $\beta$-mediated signaling is involved in the progression of diabetic nephropathy, and high levels of TGF- $\beta$ are found in diabetic kidneys.

Natural products and their active constituents have been reportedly used for the treatment of diabetes and diabetic complications [10]. The genus Allium comprises more than 600 different species distributed throughout North America, North Africa, Europe, and Asia. Many Allium species have been utilized in folk medicine throughout the world for the treatment of various physical disorders such as burns, wounds, headaches, chest colds, and rheumatism [12]. Allium victorialis var. platyphyllum (Liliaceae), one of the most popular Allium species, is an edible perennial herb widely distributed on Ulleung Island and Mt. Hambeak of the Korean Peninsula. Recently, Allium victorialis (A. victorialis) has received much attention owing to its diverse and potentially significant pharmacological properties including antiarteriosclerotic, anticancer, antioxidant, antidiabetic, antiobesity, antineuroinflammatory, hepatoprotective, and nephroprotective effects [12-21].
In this paper, we examined the effects of eight compounds (1-8) isolated from A. victorialis leaf on AR activity, AGE formation, and TGF- $\beta 1$ mRNA expression and protein secretion in mouse glomerular mesangial cells (MMCs) cultured under diabetic conditions. Furthermore, binding between AGE and receptor for AGE (RAGE) in human RAGE (hRAGE)-overexpressing MMCs was analyzed, and the most active compound was identified. These results show that single compounds from $A$. victorialis leaf extracts have preventive effects against diabetic nephropathy and may be useful as candidates for preclinical study in the treatment of diabetic nephropathy.

\section{Methods}

\section{Plant materials and chemicals}

The leaf of A. victorialis were purchased from a commercial supplier in Goryung, (Gyeongbuk, Korea, in January, 2005) and identified by Prof. K-R Park in the Department of Herbology, The Medical Research center for Globalization of Herbal Formulation, Daegu Haany University. A herbarium voucher specimen (no. KIOMALVI) has been deposited at the Herbarium of the Diabetic Complications Research Group, Korea Institute of Oriental Medicine. Antibodies were purchased from Cell Signaling (Beverly, MA) and Santa Cruz Biotechnology (Santa Cruz, CA). All other reagents were obtained from Sigma-Aldrich (St. Louis, MO). Reagents used for cell culture were purchased from GIBCO-BRL (Grand Island, NY).

\section{General experimental procedures}

Optical rotations were measured on a JASCO P-2000 digital polarimeter. Hydrogen $1(300 \mathrm{MHz})$ and carbon 13 nuclear magnetic resonance (NMR; $75 \mathrm{MHz}$ ) spectra were obtained using a Bruker DRX-300 spectrometer with tetramethylsilane as an internal standard. Twodimensional-NMR experiments (correlation spectroscopy, heteronuclear multiple-quantum correlation, and heteronulear multiple bond correlation) were run on a Bruker Avance 500 NMR spectrometer. Electrospray ionization mass spectrometry spectra were recorded on a Shimadzu liquid chromatography-mass spectrometryion trap-time of flight spectrometer. Column chromatography was performed using silica gel (70-230 mesh, Merck), YMC-gel ODS-A (12 nm, S-75 $\mu \mathrm{m}, \mathrm{YMC})$, and Sephadex LH-20 (Amersham Pharmacia Biotech). Thinlayer chromatography was performed on pre-coated silica gel $60 \mathrm{~F}_{254}(0.25 \mathrm{~mm}$, Merck $)$ and RP-18 $\mathrm{F}_{254 \mathrm{~s}}$ plates $(0.25 \mathrm{~mm}$, Merck). Spots were detected by utraviolet light $(254 \mathrm{~nm})$ and spraying with $10 \% \mathrm{H}_{2} \mathrm{SO}_{4}$ followed by heating. 


\section{Extraction and isolation}

The air-dried leaf of $A$. victorialis $(4.0 \mathrm{~kg}$ ) were extracted with $50 \% \mathrm{EtOH}(36 \mathrm{~L})$ at $60^{\circ} \mathrm{C}$ for $5 \mathrm{~h}$, filtered, and concentrated to yield a $50 \% \mathrm{EtOH}$ extract $(1.0 \mathrm{~kg})$. This extract $(1.0 \mathrm{~kg})$ was suspended in $\mathrm{H}_{2} \mathrm{O}(4 \mathrm{~L})$ and then partitioned successively with EtOAc $(3 \times 4.0 \mathrm{~L})$ and $n$ $\mathrm{BuOH}(3 \times 4.0 \mathrm{~L})$ to afford EtOAc- $(13 \mathrm{~g})$ and $n$ - $\mathrm{BuOH}-$ soluble fractions $(258 \mathrm{~g})$, respectively. The EtOAc- (12 g) and $n$ - $\mathrm{BuOH}$-soluble fractions $(250 \mathrm{~g})$ were subjected to a series of chromatographic techniques including silica gel, YMC RP-18, and Sephadex LH-20 column chromatographies, leading to the isolation of eight compounds (1-8, Table 1), Kaempferol 3,7,4'-O- $\beta$-D-triglucopyranoside (1, $280 \mathrm{mg})$, Kaempferol 3,7-O- $\beta$-D-diglucopyranoside (2, $66 \mathrm{mg})$, kaempferol 3,4'-O- $\beta$-D-diglucopyranoside (3, $70 \mathrm{mg})$, quercitrin $(\mathbf{4}, 10 \mathrm{mg})$, kaempferol $(\mathbf{5}, 24 \mathrm{mg})$, quercetin $(6,45 \mathrm{mg})$, 4-hydroxycinnamic acid (7, $4.3 \mathrm{mg})$, and ferulic acid (8, $10 \mathrm{mg})$.

\section{Rat lens AR activity}

AR activity was measured as described previously [9,22]. All animal procedures were approved by the Korea Institute of Oriental Medicine Institutional Animal Care Committee on animal care at our institute and conducted according to institutional guidelines. Rat lenses were isolated from the eyes of 8-week-old Sprague-Dawley rats (Orient Co., Seongnam, Korea) and homogenized in 12 volumes of 150 $\mathrm{mM}$ sodium phosphate buffer $(\mathrm{pH}$ 6.2) and $10 \mathrm{mM} 2$ mercaptoethanol. The homogenate was centrifuged at $14,000 \mathrm{rpm}$ for $30 \mathrm{~min}$, and the supernatant was used as crude rat lens AR. The incubation mixture contained 150 $\mathrm{mM}$ sodium phosphate buffer, $0.15 \mathrm{mM}$ nicotinamide adenine dinucleotide phosphate (NADPH), $10 \mathrm{mM} \mathrm{DL-glyc-}$ eraldehyde as a substrate, and $700 \mu \mathrm{g} / \mathrm{ml}$ of enzyme substrate, with or without compounds or positive control, in a total volume of $1.0 \mathrm{ml}$. The reaction was initiated by the addition of $\mathrm{NADPH}$ at $37^{\circ} \mathrm{C}$ and stopped by the addition of $0.15 \mathrm{ml}$ of $0.5 \mathrm{~N} \mathrm{HCl}$. Next, $0.5 \mathrm{ml}$ of $6 \mathrm{M}$ $\mathrm{NaOH}$ containing $10 \mathrm{mM}$ imidazole was added, and the solution was heated at $60^{\circ} \mathrm{C}$ for $15 \mathrm{~min}$ to convert NADP to a fluorescent product. The fluorescence (ex. $360 \mathrm{~nm} / \mathrm{em}$. $460 \mathrm{~nm}$ ) was assayed using a spectrofluorometric detector (Synergy HT, Bio-Tek, Winooski, VT). The concentration of each test sample that inhibited activity by $50 \%\left(\mathrm{IC}_{50}\right)$ was estimated from the least-squares regression line of the logarithmic concentration plotted against the remaining activity.

\section{Determination of AGEs formation}

AGEs formation assay was performed as previously described [23,24]. Bovine serum albumin (BSA, $10 \mathrm{mg} / \mathrm{ml}$, Sigma-Aldrich) in $50 \mathrm{mM}$ phosphate buffer ( $\mathrm{pH} 7.4$ ) with containing $0.02 \%$ sodium azide to prevent bacterial growth was added to $0.2 \mathrm{M}$ fructose and glucose. The reaction mixture was then mixed with compounds or aminoguanidine (AG, Sigma-Aldrich). After incubating at $37^{\circ} \mathrm{C}$ for 7 days, the fluorescent reaction products were assayed on a spectrofluorometric detector (BIOTEK, Synergy HT, Ex: 350 nm/Em: 450 nm). AGEs assay was performed in quadruplicate. The concentration of each test sample giving $50 \%$ inhibition of the activities $\left(\mathrm{IC}_{50}\right)$ was estimated from the least-squares regression line of the logarithmic concentration plotted against the remaining activity.

\section{Cell Cultures}

Mouse kidney mesangial cells (SV40 MES13, MMC) were obtained from the American Type Culture Collection (\#CRL-1927, Rockville, MD) and cultured in Dulbecco's modified Eagle's medium:F-12 (3:1) supplemented with 14

Table 1 Inhibitory effect of extracts, fractions, and compounds isolated from A. victorialis on AR and AGEs formation

\begin{tabular}{|c|c|c|c|c|}
\hline No. & Extracts, fractions, and isolated compounds & Mw & AR IC 50 & AGEs $I C_{50}$ \\
\hline 1 & Kaempferol 3,7,4'-O- $\beta$-D-triglucopyranoside & 772.66 & $>50 \mu \mathrm{M}$ & $>100 \mu \mathrm{M}$ \\
\hline 2 & Kaempferol 3,7-O- $\beta$-D-diglucopyranoside & 610.52 & $>50 \mu \mathrm{M}$ & $56.44 \pm 1.39 \mu \mathrm{M}$ \\
\hline 3 & Kaempferol 3,4'-O- $\beta$-D-diglucopyranoside & 610.52 & $9.77 \pm 0.33 \mu \mathrm{M}$ & $59.66 \pm 1.22 \mu \mathrm{M}$ \\
\hline 4 & Quercitrin & 448.38 & $0.17 \pm 0.10 \mu \mathrm{M}$ & $4.20 \pm 0.04 \mu \mathrm{M}$ \\
\hline 5 & Kaempferol & 286.24 & $1.10 \pm 0.63 \mu \mathrm{M}$ & $36.01 \pm 1.40 \mu \mathrm{M}$ \\
\hline 6 & Quercetin & 302.24 & $3.61 \pm 0.19 \mu \mathrm{M}$ & $27.10 \pm 0.11 \mu \mathrm{M}$ \\
\hline 7 & 4-Hydroxycinnamic acid & 164.16 & $>50 \mu \mathrm{M}$ & $9.92 \pm 0.11 \mu \mathrm{M}$ \\
\hline 8 & Ferulic acid & 194.16 & $>50 \mu \mathrm{M}$ & $7.50 \pm 0.20 \mu \mathrm{M}$ \\
\hline 9 & A. victorialis $50 \% \mathrm{EtOH}$ & & $>10 \mu \mathrm{g} / \mathrm{ml}$ & $>75 \mu \mathrm{g} / \mathrm{ml}$ \\
\hline 10 & A. victorialis EtOAc & & $7.53 \pm 0.02 \mu \mathrm{g} / \mathrm{ml}$ & $30.13 \pm 1.68 \mu \mathrm{g} / \mathrm{ml}$ \\
\hline 11 & A. victorialis $\mathrm{BuOH}$ & & $>10 \mu \mathrm{g} / \mathrm{ml}$ & $>75 \mu \mathrm{g} / \mathrm{ml}$ \\
\hline 12 & Tetramethyleneglutaric acid & 186.20 & $5.07 \pm 0.06 \mu \mathrm{M}(0.94 \pm 0.01 \mu \mathrm{g} / \mathrm{ml})$ & - \\
\hline 13 & Aminoguanidine & 74.1 & - & $1.03 \pm 0.07 \mathrm{mM}(76.47 \pm 4.81 \mu \mathrm{g} / \mathrm{ml})$ \\
\hline
\end{tabular}


mM HEPES, penicillin $100 \mathrm{U} / \mathrm{ml}$, streptomycin $100 \mu \mathrm{g} / \mathrm{ml}$, and $5 \%$ fetal bovine serum. Cells were routinely grown to confluence in a humidified $37^{\circ} \mathrm{C}, 5 \% \mathrm{CO}_{2}$ incubator.

\section{RNA extraction and semi-quantitative reverse} transcription-polymerase chain reaction (RT-PCR) analysis Total cellular RNA was extracted with TRIzol (Invitrogen, Carlsbad, CA), quantified by measuring the absorbance at $260 \mathrm{~nm}$, and stored at $-80^{\circ} \mathrm{C}$ until analysis. The expression of TGF- $\beta 1$ and GAPDH mRNAs was detected by RT-PCR analysis. The extracted RNA $(1 \mu \mathrm{g})$ was subjected to a reverse transcriptase reaction with the Maxime RT premix (Intron, Daejeon, Korea) at $42^{\circ} \mathrm{C}$ for $60 \mathrm{~min}$ and $72^{\circ} \mathrm{C}$ for $10 \mathrm{~min}$. Subsequently, semi-quantitative PCR was performed with Accupower ${ }^{\circ}$ PCR premix (Intron, Daejeon, Korea). The primer sequences were as follows: mouse TGF- $\beta 1$ (sense) 5' - TGA ACC AAG GAG ACG GAA TAC AGG -3', (anti-sense) 5'- GCC ATG AGG AGC AGG AAG GG -3' and mouse GAPDH (sense) 5'- ACG GCA AAT TCA ACG GCA CAG -3', (anti-sense) 5'- AGA CTC CAC GAC ATA CTC AGC AC -3'. Aliquots of PCR products were electrophoresed on $1.2 \%$ agarose gels and visualized after ethidium bromide staining.

\section{Determination of secreted TGF- $\beta 1$ expression in MMCs using enzyme-linked immunosorbent assay (ELISA)}

The levels of TGF- $\beta 1$ in the medium were determined as described previously [9]. The medium was replaced with serum-free medium containing compound under high glucose conditions for $24 \mathrm{~h}$. This medium was then harvested and TGF- $\beta 1$ was activated by treatment with $1 \mathrm{~N} \mathrm{HCl}(0.1 \mathrm{ml} / 0.5 \mathrm{ml}$ of conditioned media) for 10 $\min$ at room temperature, then $0.1 \mathrm{ml} 1.2 \mathrm{~N} \mathrm{NaOH} / 0.5$ $M$ HEPES was added. Quantikine mouse TGF- $\beta 1$ ELISA (R\&D systems, Minneapolis, $\mathrm{MN}$ ) was performed according to the manufacturer's protocol, and the TGF- $\beta 1$ levels were normalized to those of total protein. Medium without cells that had been incubated under the same conditions was used as a control for the ELISA.

\section{Detection of live cell-based AGE-BSA/RAGE binding}

AGE-BSA/RAGE binding in the cells was determined as described previously [23]. Briefly, Alexa 488 labeling of AGE-BSA was performed using the Alexa Fluor ${ }^{\bullet} 488$ protein labeling kit (Molecular Probes, Eugene, OR). For the binding assay, human RAGE-overexpressing cells $\left(1 \times 10^{4}\right)$ were seeded onto a 96-well assay plate with a clear bottom lid and black plate (Corning, NY) and incubated with serum-free media for $24 \mathrm{~h}$. Before binding, $3 \%$ BSA was added for $30 \mathrm{~min}$ to block non-specific binding. Cells were treated with $5 \mu \mathrm{g}$ of Alexa Fluor 488-labeled AGE-BSA in a total volume of $100 \mu \mathrm{l}$ serum-free medium and incubated in the dark for $6 \mathrm{~h}$ in a $5 \% \mathrm{CO}_{2}$ humidified atmosphere at $37^{\circ} \mathrm{C}$. Compounds were added after the addition of AGE-BSA-Alexa Fluor 488 to hRAGE-overexpressing cells. The non-specific binding of AGE-BSA-Alexa Fluor 488 to cell surface proteins other than hRAGE was compared by incubating cells with untreated cells (blank). After binding, $100 \mu \mathrm{l}$ Opti-MEM were added to the washed plates, and the plates were then analyzed using a microtiter plate reader (Bio-Tek, Winooski, VT) with excitation and emission wavelengths of 485 and $528 \mathrm{~nm}$, respectively.

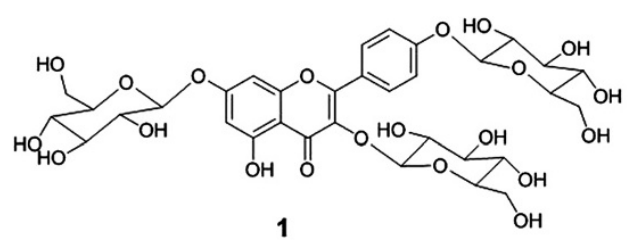

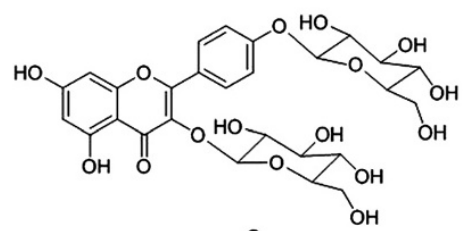

3<smiles>O=c1c(O)c(-c2ccc(O)c(O)c2)oc2cc(O)cc(O)c12</smiles>

6<smiles>CC(O)C1C(O)C(O)C(Oc2c(-c3ccc(O)c(O)c3)oc3cc(O)cc(O)c3c2=O)C(O)C1O</smiles><smiles>O=C(O)C=Cc1ccc(O)cc1</smiles>

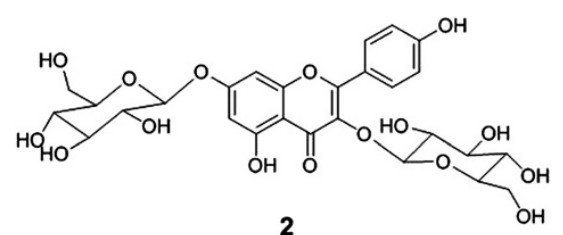<smiles>O=c1c(O)c(-c2ccc(O)cc2)oc2cc(O)cc(O)c12</smiles>

5<smiles>COc1cc(/C=C/C(=O)O)ccc1O</smiles>

8

Figure 1 Structures of the compounds (1-8) isolated from the leaf of $A$. victorialis. 


\section{Statistical analysis}

Data are expressed as mean \pm S.E.M. of multiple experiments. Paired Student's $t$-tests were used to compare two groups, or analysis of variance with Tukey's was used for multiple comparison tests using PRISM software (Graph Pad, San Diego, CA). Values of $p<0.05$ were considered statistically significant.

\section{Results and discussion}

\section{Structure elucidation of compounds}

The EtOAc- and $n$-BuOH-soluble fractions were subjected to a series of chromatographic techniques, leading to the isolation of eight known compounds (1-8) (Figure 1). These compounds were identified as kaempferol 3,7,4'-O- $\beta$-D-triglucopyranoside (1), kaempferol 3,7-O- $\beta$-D-diglucopyranoside (2), kaempferol 3,4'-O- $\beta$-D-diglucopyranoside (3), quercitrin (4), kaempferol (5), quercetin (6), 4-hydroxycinnamic acid (7), and ferulic acid (8) by comparing their physicochemical and spectral data to those in the literature [25-31].

\section{Rat lens AR activity, AGE formation, and AGE/RAGE- binding in hRAGE-overexpressing cells}

ARIs suppressing the hyperglycemia-induced polyol pathway have been identified as potential therapeutic candidates in the treatment and prevention of diabetic complications. The $\mathrm{IC}_{50}$ values of compounds (Table 1) in this assay were comparable to that those of known ARIs, such as TMG, which suggested that the compounds and extracts appeared to have an inhibitory effect on AR activity. Among the compounds, quercitrin (4), kaempferol (5), and quercetin (6) were significantly more potent than the previously known positive control, TMG. Previous research also demonstrated that flavonoids such as quercetin and myricitrin are effective inhibitors of lens AR [28]. We previously reported that quercitrin gallate also inhibits AR activity and xyloseinduced lens opacity and oxidation [25]. Kaempferol and its prenylated derivatives are reported to be aldolase inhibitor [32]. Kaempferol 3,4'-O- $\beta$-D-diglucopyranoside (3) $\left(\mathrm{IC}_{50}=9.77 \pm 0.33 \mu \mathrm{M}\right)$ and the $A$. victorialis EtOAc- soluble fraction $\left(\mathrm{IC}_{50}=7.53 \pm 0.02 \mu \mathrm{g} / \mathrm{ml}\right)$ inhibited AR activity. Although, $\mathrm{IC}_{50}$ level of EtOAcsoluble fraction was higher than TMG $(0.94 \pm 0.01 \mu \mathrm{g} /$ $\mathrm{ml}$ ), among the extracts, it has the inhibitory effects on AGEs formation $\left(\mathrm{IC}_{50}=30.13 \pm 1.68 \mu \mathrm{g} / \mathrm{ml}\right.$; $\mathrm{AG}, \mathrm{IC}_{50}=$ $76.47 \pm 4.81 \mu \mathrm{g} / \mathrm{ml})$. Previous research indicated that genistein has inhibitory effects of AR activity in vitro, AGEs formation, and AGE-RAGE binding in hRAGEoverexpressing cells $[9,23]$. Next, we examined the inhibitory effects of compounds and extracts on AGEs formation (Table 1). Quercitrin (4) $\left(\mathrm{IC}_{50}=4.20 \pm 0.04 \mu \mathrm{M}\right)$ and ferulic acid $(8)\left(\mathrm{IC}_{50}=7.50 \pm 0.20 \mu \mathrm{M}\right)$ exhibited inhibitory effects on AGEs formation. Furthermore, because of the pronounced inhibitory effect of the three compounds (4, 5, and 6) on AR and AGEs formation, AGE-RAGE binding assays were performed in hRAGEoverexpressing cells (Figure 2). Among the compounds, quercitrin (4) significantly inhibited AGE-RAGE binding in hRAGE-overexpressing cells. Although quercitrin (4) has been tested on ARI effect [28], this compound has never been examined for the AGE-RAGE binding assay in hRAGE-overexpressing cells up to data. Quercitrin has anti-inflammatory effect through the inhibition of the NF-kappa B pathway and it shows potential anticancer effect, including cell cycle regulation and tyrosine kinase inhibition [33,34].

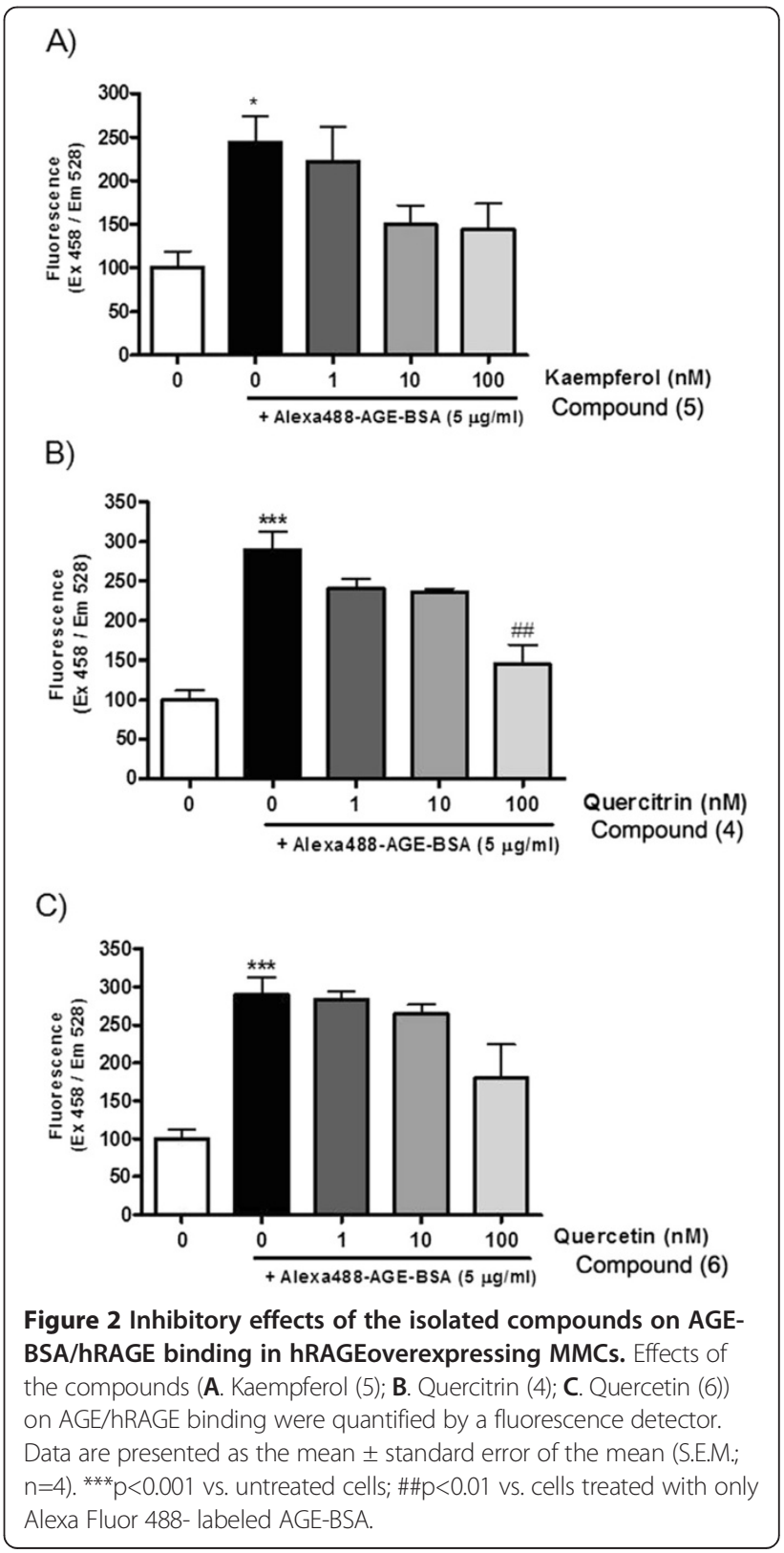




\section{Inhibition of high glucose-induced TGF- $\beta 1$ expression and secretion in MMCs}

TGF- $\beta 1$ stimulates the production of ECM proteins such as fibronectin and collagen and promotes mesangial cell expansion [35,36]. In diabetic nephropathy, these changes are associated with the development of basement membrane thickening in the glomeruli [37]. Thus, TGF- $\beta 1$ is considered a potential therapeutic target in diabetic nephropathy and other chronic renal diseases. To assess which compounds from A. victorialis are involved in the regulation of both TGF- $\beta 1$ mRNA and protein levels in MMCs under diabetic conditions, cells were treated with high glucose in the presence or absence of single compounds (1-8) for $48 \mathrm{~h}$. As shown in Figure $3 \mathrm{~A}$ and $\mathrm{B}$, single compounds (1-8) inhibited TGF- $\beta 1$ mRNA expression in high glucose-stimulated MMCs $\left({ }^{* * * *} \mathrm{p}<0.001\right.$, vs. C; \#\#\# $<0.001$, \#\#p $<0.01, \# \mathrm{p}<0.05$ vs. HG). Furthermore, we demonstrated that compounds from $A$. victorialis inhibit high glucose-induced TGF- $\beta 1$ secretion (Figure 4, ${ }^{* * * * *} \mathrm{p}<0.001$, vs. C; \#\#\# $<0.001, \# \# \mathrm{p}<0.01$, $\# \mathrm{p}<0.05$ vs. HG). Among the eight compounds identified from $A$. victorialis, ferulic acid (8) displayed the greatest inhibitory effect on TGF- $\beta 1$ expression in MMCs. A previous study suggested that ferulic acid have protective effects against diabetic nephropathy by reducing oxidative stress and inflammation in a rat model of type 2 diabetes [38]. In the present study, we first demonstrated that the treatment

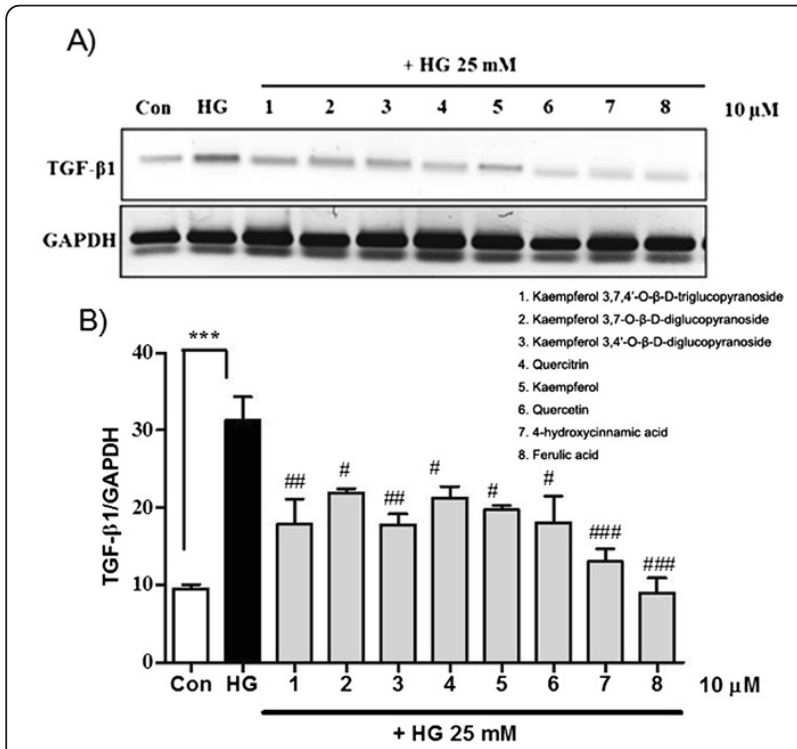

Figure 3 Inhibitory effect of the compounds isolated from $A$. victorialis on high glucose-induced TGF- $\beta 1$ mRNA expression. Quiescent MMCs were treated with high glucose for $48 \mathrm{~h}$ followed by 10 $\mu \mathrm{M}$ of the compounds (1-8). Kaempferol 3,7,4'-O- $\beta$-D-triglucopyranoside (1), kaempferol 3,7-O- $\beta$-D-diglucopyranoside (2), kaempferol 3,4'-O-B-Ddiglucopyranoside (3), quercitrin (4), kaempferol (5), quercetin (6), 4hydroxycinnamic acid (7), and ferulic acid (8). TGF- $\beta 1$ mRNA expression was determined by relative RT-PCR. Results are the mean \pm S.E.M. $(n=3)$.

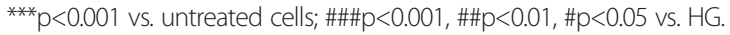

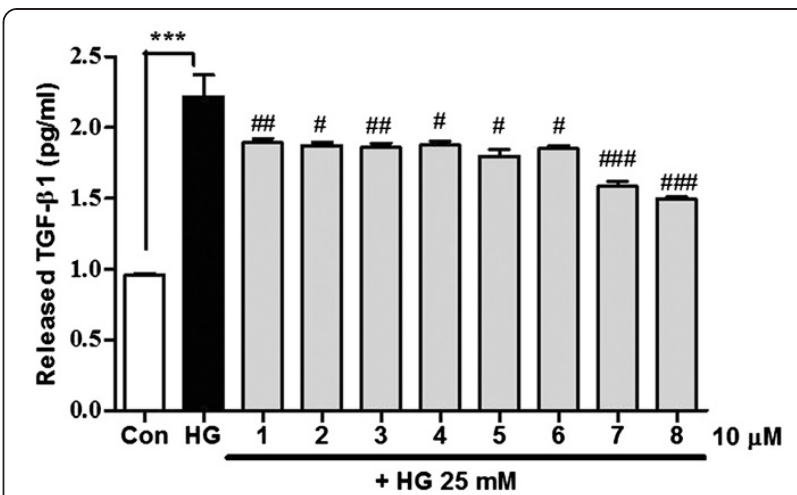

Figure 4 Inhibitory effect of the compounds isolated from $A$. victorialis on high glucose-induced TGF- $\beta 1$ secretion. Quiescent MMCs were treated with high glucose for $48 \mathrm{~h}$ followed by $10 \mu \mathrm{M}$ of the compounds (1-8). To determine the amount of secreted TGF$\beta 1$ protein in the medium, ELISAs were performed on MMCs treated with high glucose. Experiments were done in triplicate on three separate occasions. Results are the mean \pm S.E.M. $(n=4) .{ }^{* * *} p<0.001$ vs. untreated cells; \#\#\#p<0.001, \#\#p<0.01,\#p<0.05 vs. HG.

of MMCs with single compounds from $A$. victorialis inhibited high glucose-induced TGF- $\beta 1$ mRNA expression. However, toxicology study in vivo is needed to evaluate the safety of $A$. victorialis in the drug development.

\section{Conclusion}

In summary, our data suggest that active compounds isolated from $A$. victorialis leaf exhibit inhibitory effects on AR activity and AGE formation. Further, ferulic acid reduces TGF- $\beta 1$ mRNA expression and secretion in MMCs under diabetic conditions. Thus, the compounds isolated from $A$. victorialis leaf provide some scientific evidence to support the folk medicinal utilization of $A$. victorialis in the treatment of diabetic nephropathy. Furthermore, A. victorialis is a good candidate for the development of treatments for diabetic nephropathy.

\section{Competing interests}

The authors declare that they have no competing interests.

\section{Authors' contributions}

YSK and JSK: Designed the study and wrote the manuscript; DHJ: Carried out the RAGE-AGE binding assay and cell culture experiments; SJC: Carried out the AGE and AR assays; ISL and SYY: Carried out the isolation of compounds; ISL: Helped to write draft the manuscript; SKK, MHK and JSK: Helped to discuss and supervised the work. All authors read and approved the final manuscript.

\section{Acknowledgements}

This research was supported by grant [K12040] from the Korea Institute of Oriental Medicine (KIOM) and by grant [10039320] from the Global Leading Technology Program of the Office of Strategic R\&D Planning (OSP) funded by the Ministry of Knowledge Economy, Republic of Korea. The authors would like to thank Prof. Kyu-Ryul Park, PhD; Department of Herbology, The Medical Research center for Globalization of Herbal Formulation, Daegu Haany University for identification of plant.

\section{Author details}

${ }^{1}$ Korean Medicine-Based Herbal Drug Development Group, Herbal Medicine Research Division, Korea Institute of Oriental Medicine (KIOM), Daejeon, 
Republic of Korea. ${ }^{2}$ Developmnent Team for the New Drug of Oriental Medicine, Daegu Haany University, Gyeongsan, Republic of Korea. ${ }^{3}$ Jeil Pharmaceutical CO., LTD, Yongin, Kyonggi-do, Republic of Korea. ${ }^{4}$ Present address: Korea Drug Development Fund, 21-1 Migeun-dong, Seodaemun-gu, Seoul 120-020, Republic of Korea.

Received: 2 July 2013 Accepted: 26 September 2013

Published: 3 October 2013

\section{References}

1. Huebschmann AG, Regensteiner JG, Vlassara H, Reusch JE: Diabetes and advanced glycoxidation end products. Diabetes Care 2006, 29:1420-1432.

2. Brownlee M: The pathobiology of diabetic complications: a unifying mechanism. Diabetes 2005, 54:1615-1625.

3. Hotta N, Toyota T, Matsuoka K, Shigeta Y, Kikkawa R, Kaneko T, Takahashi A Sugimura K, Koike Y, Ishii J, Sakamoto N: Clinical efficacy of fidarestat, a novel aldose reductase inhibitor, for diabetic peripheral neuropathy: a 52-week multicenter placebo-controlled double-blind parallel group study. Diabetes Care 2001, 24:1776-1782.

4. Kinoshita JH, Dvornik D, Kraml M, Gabbay KH: The effect of an aldose reductase inhibitor on the galactose-exposed rabbit lens. Biochim Biophys Acta 1968, 158:472-475.

5. Obrosova IG, Minchenko AG, Vasupuram R, White L, Abatan OI, Kumagai AK, Frank RN, Stevens MJ: Aldose reductase inhibitor fidarestat prevents retinal oxidative stress and vascular endothelial growth factor overexpression in streptozotocin-diabetic rats. Diabetes 2003, 52:864-871.

6. Itagaki I, Shimizu K, Kamanaka Y, Ebata K, Kikkawa R, Haneda M, Shigeta Y: The effect of an aldose reductase inhibitor (Epalrestat) on diabetic nephropathy in rats. Diabetes Res Clin Pract 1994, 25:147-154.

7. Sung JK, Koh JH, Lee MY, Kim BH, Nam SM, Kim JH, Yoo JH, Kim SH, Hong SW, Lee EY, Choi R, Chung $\mathrm{CH}$ : Aldose reductase inhibitor ameliorates renal vascular endothelial growth factor expression in streptozotocin-induced diabetic rats. Yonsei Med J 2010, 51:385-391.

8. de la Fuente JA, Manzanaro S: Aldose reductase inhibitors from natural sources. Nat Prod Rep 2003, 20:243-251.

9. Kim YS, Kim NH, Jung DH, Jang DS, Lee YM, Kim JM, Kim JS: Genistein inhibits aldose reductase activity and high glucose-induced TGF-beta2 expression in human lens epithelial cells. Eur J Pharmacol 2008, 594:18-25.

10. Marles RJ, Farnsworth NR: Antidiabetic plants and their active constituents,". Phytomedicine 1995, 2:137-189.

11. Roberts $A B, M c C$ une BK, Sporn MB: TGF-beta: regulation of extracellular matrix. Kidney Int 1992, 41:557-559.

12. Block E: Flavorants from garlic, onion, and other Alliums and their cancer-preventive properties in food phytochemicals for cancer prevention. In Food Phytochemicals for Cancer Prevention I. ACS Symposium Series, 546. Washington, DC: American Chemical Society; 1994:84-96.

13. Lee KT, Choi JH, Kim DH, Son KH, Kim WB, Kwon SH, Park HJ: Constituents and the antitumor principle of Allium victorialis var. platyphyllum. Arch Pharm Res 2001, 24:44-50.

14. Shirataki Y, Motohashi N, Tani S, Sunaga K, Sakagami H, Satoh K, Nakashima $\mathrm{H}$, Kanamoto T, Wolfard K: Antioxidative activity of Allium victorialis L. extracts ",". Anticancer Res 2001, 21:3331-3339.

15. Kim TG, Kim SH, Kang SY, Jung KK, Choi DH, Park YB, Ryu JH, Han HM: Antiatherogenic effect of the extract of Allium victorialis on the experimental atherosclerosis in the rabbit and transgenic mouse,". Kor. J. Pharmacogn 2000, 31:149-156.

16. Lee KT, Choi JH, Kim DH, Son KH, Kim WB, Kwon SH, Park HJ: Constituents and the antitumor principle of Allim victorials var. platyphyllum. Arch Pharm Res vol 2001, 24:44-50.

17. Woo KW, Moon E, Park SY, Kim SY, Lee SY: Flavonoid glycosides from the leaves of Allium victorialis var. platyphyllum and their antineuroinflammatory effects. Bioorg Med Chem Lett 2012, 22:7465-7470.

18. Ahn YM, Lim SJ, Han HK, Choi SS: Effects of Allim vegetable intake on levels of plasma glucose, lipid and minerals in streptozotocin induced diabetic rat. Korean I Nutrition 2006, 39:433-443.

19. Ku SK, Chung IK, Chen WH, Kim J-W: Allium victorials Leaf Extract Prevents High Fat Diet Induced Obesity in Mice. J Vet Clin vol 2011, 28:280-286.

20. Choi JW, Lee KT, Kim WB: Phamacological effects of the Allim victorials var. platyphyllum extracts on the rats induced by streptozotocin, poloxamer-407, $\mathrm{CCl}_{4}$ and D-galactosamine. Kor J Pharmacogn 2003, 34:250-255.
21. Ku SK, Kim JW: Hepatoprotective and nephroprotective effects of Allim victorials leaf extracts on the high fat diet supplied mice. J Vet Clin 2010, 27:225-231

22. Dufrane SP, Malaisse WJ, Sener A: A micromethod for the assay of aldose reductase, its application to pancreatic islets. Biochem Med 1984, 32:99-105.

23. Jung DH, Kim YS, Kim JS: Screening system of blocking agents of the receptor for advanced glycation endproducts in cells using fluorescence. Biol Pharm Bull 2012, 35:1826-1830.

24. Jang DS, Lee GY, Lee YM, Kim YS, Sun H, Kim DH, Kim JS: Flavan-3-ols having a gamma-lactam from the roots of Actinidia arguta inhibit the formation of advanced glycation end products in vitro. Chem Pharm Bull (Tokyo) 2009, 57:397-400

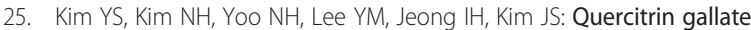
inhibits aldose reductase activity and xylose-induced lens opacity and oxidation. Biomed \& Aging Path 2011, 1:123-127.

26. Wieslawa B, Irena M: Flavonoids from Aquilegia vulgaris L. flowers. Acta Pol Pharm Drug Res 1999, 56:241-244.

27. Michael HN, Shafik RE, Rasmy GE: Studies on the chemical constituents of fresh leaf of Eruca sativa extract and its biological activity as anticancer agent in vitro. J Med Plants Res 2011, 5:1184-1191.

28. Mok SY, Lee S: Identification of flavonoids and flavonoid rhamnosides from Rhododendron mucronulatum for. albiflorum and their inhibitory activities against aldose reductase. Food Chem 2013, 136:969-974.

29. Agrawal PK: Carbone-13 NMR of flavonoids. New York: Elsevier; 1989.

30. Ma SJ, Kuk JH, Ko B: Isolation and characterization of 4-hydroxycinnamic acid with antimicrobial activity from Aralia elata. Agri Chem Biotech 1996 39:265-267.

31. Lee HJ, Lee SK, Choi DH: Extractives from the Allium victorials. J Korean For Soc vol 2007, 96:620-624.

32. Jung HA, Moon HE, Oh SH, Kim BW, Sohn HS, Choi JS: Kinetics and molecular docking studies of kaempferol and its prenylated derivatives as aldose reductase inhibitors. Chem Biol Interact 2012, 197:110-118.

33. Lamson DW, Brignall MS: Antioxidants and cancer, part 3: quercetin. Altern Med Rev 2000, 5:196-208

34. Comalada M, Camuesco D, Sierra S, Ballester I, Xaus J, Gálvez J, Zarzuelo A In vivo quercitrin anti-inflammatory effect involves release of quercetin, which inhibits inflammation through down-regulation of the NF-kappaB pathway. Eur I Immunol 2005, 35:584-592.

35. Jung DH, Kim YS, Kim JS: KIOM-79 prevents S100b-induced TGF-beta1 and fibronectin expression in mouse mesangial cells. J Ethnopharmacol vol 2009, 125:374-379.

36. Han DC, Hoffman BB, Hong SW, Guo J, Ziyadeh FN: Therapy with antisense TGF-beta1 oligodeoxynucleotides reduces kidney weight and matrix mRNAs in diabetic mice. Am J Physiol Renal Physiol 2000, 278:F628-F634.

37. Sharma K, Ziyadeh FN: Hyperglycemia and diabetic kidney disease. The case for transforming growth factor-beta as a key mediator. Diabetes 1995, 44:139-1146.

38. Choi R, Kim BH, Naowaboot J, Lee MY, Hyun MR, Cho EJ, Lee ES, Lee EY, Yang YC, Chung CH: Effects of ferulic acid on diabetic nephropathy in a rat model of type 2 diabetes. Exp Mol Med 2011, 43:676-683.

doi:10.1186/1472-6882-13-251

Cite this article as: Kim et al: Effects of Allium victorialis leaf extracts and its single compounds on aldose reductase, advanced glycation end products and TGF- $\beta 1$ expression in mesangial cells. BMC Complementary and Alternative Medicine 2013 13:251. 